総 説

\title{
スピントロニクスの形成と発展
}

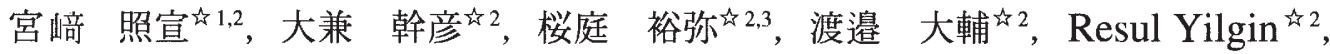

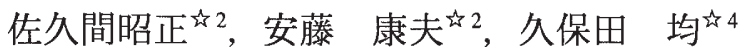

41 東北大学原子分子材料科学高等研究機構 (WPI), T 980-8579 仙台市青葉区荒巻字青葉 6-6-04, ハッチエリースクエア.

42 東北大学大学院工学研究科, 干 980-8579 仙台市青葉区荒巻字青葉 6-6-05.

的東北大学金属材料研究所, $\bar{T} 980-8577$ 仙台市青葉区片平 2-1-1.

故産業技術総合研究所, テ305-8568 つくば市梅園 1-1-1。

\section{Formation and Developments of Spintronics Research Field}

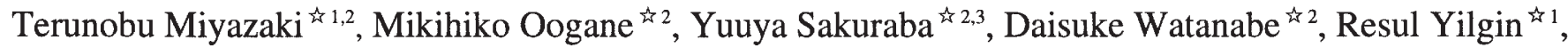 \\ Akimasa Sakuma ${ }^{\text {मे }}$, Yasuo Ando ${ }^{\text {古 } 2}$ and Hitoshi Kubota ${ }^{\text {th }}$ \\ in 1 WPI Advanced Institute for Materials Research Tohoku University, Hatchery Square, \\ 6-6-04 Aramaki Aza-Aoba Aoba-ku, Sendai 980-8579, Japan. \\ ${ }^{\text {is }}{ }^{2}$ School of Engineering, Tohoku University, 6-6-05 Aoba Aramaki Aza, Aoba-ku, Sendai 980-8579, Japan. \\ ${ }^{4}$ Institute for Materials Research, Tohoku University, 2-1-1 Katahira Aoba-ku, Sendai 980-8577, Japan. \\ ${ }_{4}^{4}$ Advanced Industrial Science and Technology, 1-1-1 Umezono, Tsukuba 305-8568, Japan.
}

Received September 18, 2007

\section{SYNOPSIS}

History about the research of magnetoresistance effect was reviewed. Also, we looked back on the research trends in the past when both giant magnetoresistance of $\mathrm{Fe} / \mathrm{Cr}$ multi layered films and large tunnel magnetoresistance at room temperature were found.

Special emphasis was placed on the recent developments of huge TMR ratio for both MgO barrier tunnel junctions and Heusler alloy electrode tunnel junctions which contribute further to the development of spinelectronic research fields. Principle and importance of spin-transfer torque were also explained.

\section{KEY WORDS}

Spintronics, giant magnetoresistance effect, tunnel magnetoresistance, $\mathrm{MgO}$ barrier, Heusler alloys, spinpolarization, spin-transfer torque

\section{1 緒 言}

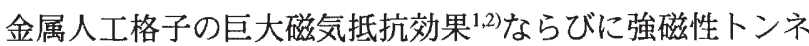
ル接合に抒ける室温での巨大トンネル磁気抵抗効果 ${ }^{3,4)}$ の発見 がトリガとなり,「スピントロニクス」と称する研究分野が過 去 20 年間の間に形成され，着実に発展してきた ${ }^{5)}$.ここでは 磁気抵抗効果研究の歴史について先ず説明する.ついで上記 の二つの大きな発見の当時の研究の様子を振り返る. 最後に 特に最近の研究発展に大きく貢献した成果のいくつかについ て記述したい.

\section{2 磁気抵抗効果研究の歴史 ${ }^{5)}$}

電磁気学を習うと磁気抵抗(magnetic resistance) という言葉 が出てくる.これはFig.1に示すように電気回路に対応して， 磁気回路を考光, 起磁力 $(n I, I$ は磁気回路を取り巻くコイルの
電流, $n$ はコイルの巻き数) を磁束 $\Phi$ (回路の断面積 $S$ と磁束 密度 $B$ の積) で割った值である.この場合の磁気抵抗は磁路 の長さに比例し, 回路を構成する磁性体の透磁率 $\mu$ とその断 面積 $S$ の積に反比例する.

これに対して, 外部から磁界を印加すると物質の電気抵抗 が変化する現象を総称して磁気抵抗効果 (magnetoresistance effect) と呼んでいる. 磁気抵抗効果に関する研究は非常に古 く, 電磁気学における Maxwell 方程式が完成した数年後の 1857 年 (William Thomson, Proc. Roy. Soc., 8(1857) 546.) まで さかのぼる.この論文はFeと Niの今で言う異方性磁気抵抗効 果の研究である.その後1960年頃までに3d遷移金属・合金の 異方性磁気抵抗効果 (anisotropic magnetoresistance effect: 略 して AMR 効果) の研究があ，1960年から1970年にかけては AMR 効果を解釈するための two current model に立脚した議論 ${ }^{7)}$ 


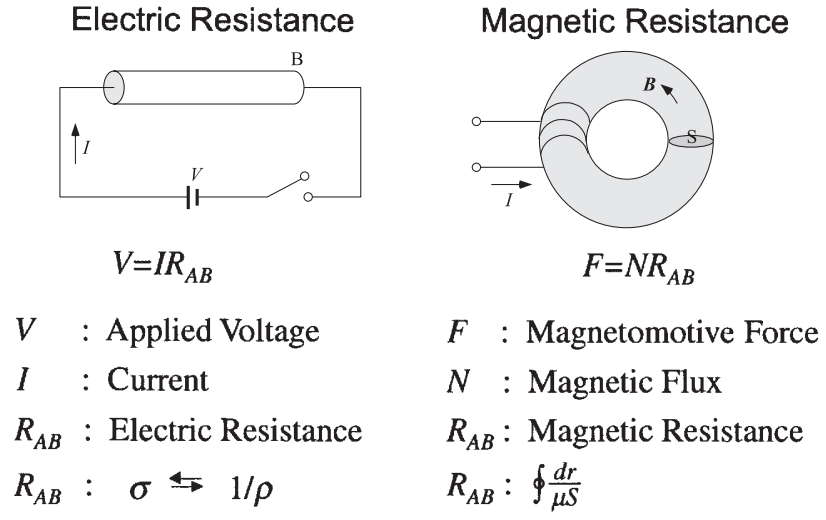

Fig.1 Electric resistance and magnetic resistance.

および磁性半導体の巨大磁気抵抗効果 ${ }^{8)}$ の研究が行われた. 金属人工格子の巨大磁気抵抗効果 (Giant magnetoresistance effect: 略してGMR効果, 以降GMR) と言う言葉が一般に知ら れるようになったが，それよりも約 20 年程前にGMR は用い られていた。

\section{3 金属人工格子の GMR 効果ならびに巨大 TMR 効果}

大きな研究成果は何もないところにぱっと生まれるはずが なく,関連したいくつかの研究の中から生まれるのが一般的 である. GMR 効果も巨大 TMR 効果もまさにそのようにして 生まれたものである.ここではそれぞれが報告された当時の 関連研究について述べる.

3.1 GMR 効果報告の項

1985 年頃, 当時の磁性薄膜研究は金属人工格子, 多首膜を 対象に, 基礎的な観点からは界面における磁気モーメントの 增大, 層間相互作用, 界面磁気異方性 (垂直磁気異方性の原 因), 磁気光学効果の增大, 応用的な観点からは新しい磁気一 光学材料,ソフトな磁性材料の開発を目指したものであった. 人工格子と言う言葉は多くの研究者に魅力を与え, 新しい機 能の創製が期待された. 特に $\mathrm{Ni} / \mathrm{Cu}$ 人工格子で $\mathrm{Ni}$ の磁気モ一 メントが大幅に増大すると言う報告は多くの磁性薄膜研究者 を人工格子の研究に駆り立てた. しかしながらこの報告はそ の後誤りであることが分かり，一部では「人工格子の研究で は新しいものが生まれないのでは」とささやかれ始めていた。 このような状況の中で 1988 年にドイツの Grünberg のグルー プとフランスのFertのグループから金属人工格子 $(\mathrm{Fe} / \mathrm{Cr})$ の巨 大磁気抵抗効果の報告がなされた. 前者は薄い非磁性物質を 強磁性薄膜で挟んだ強磁性二層構造の首間相互作用の研究か ら，磁気抵抗効果の増大を発見した．層間には反強磁性的相 互作用が㗢くが，相互作用と GMR 効果とは直接関係ないこ とが後で分かった. 一方後者の Fertは昔から磁気抵抗効果の 研究を行ってきた人物であり $\mathrm{Fe} / \mathrm{Cr}$ 多首膜研究に至ったのは 学生時代の $\mathrm{Fe}-\mathrm{Cr}$ の磁気抵抗効果の研究が出発となっている ということである.いずれにしてもこのグループの報告がそ の後の磁性薄膜研究の流れを作ることになる. 研究の歴史を


Fig.2 Magnetoresistance curve (a) and magnetic hysteresis loop (b) for $\mathrm{Fe} / \mathrm{Al}_{2} \mathrm{O}_{3} / \mathrm{Fe}$ tunnel junction.

更に詳しく知りたい方は文献 9-11) を参照していただきたい. $3.2 \mathrm{TMR}$ 効果報告の項

筆者は 1990 年に 4 年生の卒業研修のテーマとして取り上 げ, トンネル磁気抵抗 (TMR) 効果の研究をスタートした. TMR 効果の先駆的研究はJulliereであり 1975 年に既に報告さ れ，その後数グループの研究者が実験していたが, 室温では ほとんどその効果が観察されなかった. 我々が研究を始める 前の15年間の報告についてはすでにまとめて報告しているの


$\mathrm{MIT}^{4}$ のグループから室温でも $10 \%$ 以上の $\mathrm{TMR}$ 比が報告され たことにより, 次第にこの分野の研究が注目されることとな る. 特にスピンバルブタイプのトンネル接合が報告されると GMRの研究の進展と同様に応用を意図した研究が次第に多く なり,なかでも超高密度ハードディスクドライブ(HDD) およ び固体磁気メモリ(MRAM)を念頭に置いた研究が増えていっ $た^{13.14)}$.この辺の研究の進展についても既に解説しているので それを参照していただきたい ${ }^{15)}$. Fig.2には筆者らの Fe/Al-O/ Fe 接合の $M-R$ 曲線とそれに対応した磁化曲線を示す. 両者 を対応して見ると両 $\mathrm{Fe}$ 層の磁化が平行のとき抵抗が小さく, 反平行のとき抵抗が大きいことが分かる. 即ち, 磁化の向き により電流をコントロールしていることになる. Fig.3にはこ の現象論的説明として良く用いられるJulliereのモデルを示し てある.このモデルによると TMR 比は,

\section{$\frac{2 P_{1} P_{2}}{1-P_{1} P} \quad\left(P_{1(2)}\right.$ は強磁性 $1(2)$ 層の分極率を示す $)$} で与えられ，実験結果を比較的良く説明している. 
(a)

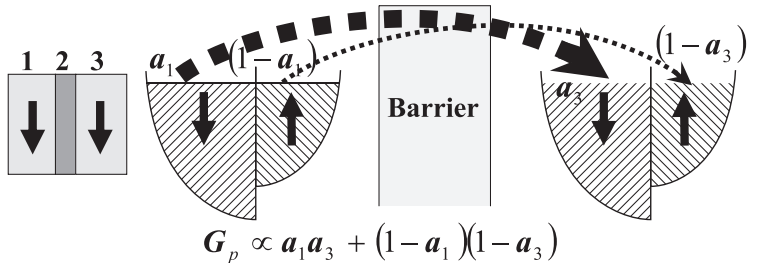

(b)

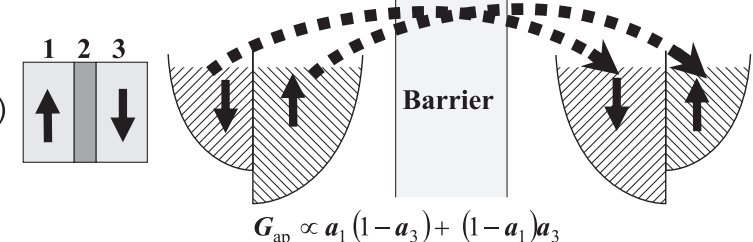

Fig.3 Density of states of upward spin ( $\uparrow$ ) electrons and downward spin ( $\downarrow$ ) electrons in (a) parallel state and (b) anti-parallel state of the magnetization of the magnetic layer Each of $a_{1}$ or $a_{3}$ is existence probability of electrons in the Fermi level.

\section{4 スピントロニクスの形成}

金属人工格子の巨大磁気抵抗効果の発見および室温でのト ンネル磁気抵抗効果の発見がトリガとなり, 磁性研究分野に おいて従来型の磁性体プロパーの研究ではなく, 磁性研究に 伝導の寄与を積極的に取り入れた研究がクローズアップされ た. 一方, 半導体の研究分野でも既存の半導体デバイスの限 界を打破すべく，磁性半導体の研究に見られるように，スピ ンの重要性が認識され，この分野で得意としてきた微細加工 技術を生かした，新しいデバイスの研究が注目された。

スピントロニクス (Spin electronics, also called spintronics, magnetoelectronics or magnetronics) とは電子の持つスピンと電 荷の双方に着目し, 最新の加工技術を用いて微細化すること により, 機能を最大限に引き出し, 新しいデバイスを創製しよ うとするものである. 概念図を Fig.4に示す．この分野の研究は ここ20年程度の歴史と考えて良い. WTEC (World Technology Evaluation Center) はNSFを援助を受け, この分野の研究のレ ビューと米国, 日本, 西欧に於ける研究活動の調査報告 ${ }^{16)}$ 2000 年代になって行っている，我が国では 21 の研究グルー プがこれについてインタビューを受けている.この報告書に よるとスピントロニクスはやや広くとらえられ以下のように 記述されている.

It covers materials, fabrication and characterization of magnetic structures, magnetism and spin control in magnetic nanostructures, magneto-optical properties of semiconductorors, and magnetoelectronics and devices

ややもすると金属系のスピントロニクス, 半導体系のスピ ントロニクスと区別されがちであるが，目的とするところは 同じで，時間スケールが若干異なるだけである.

\section{5 スピントロニクスの進展}

GMR 効果の報告, 室温での巨大 TMR 効果の発見により高 密度HDD用磁気へッド並びにMRAMをはじめとする種々の

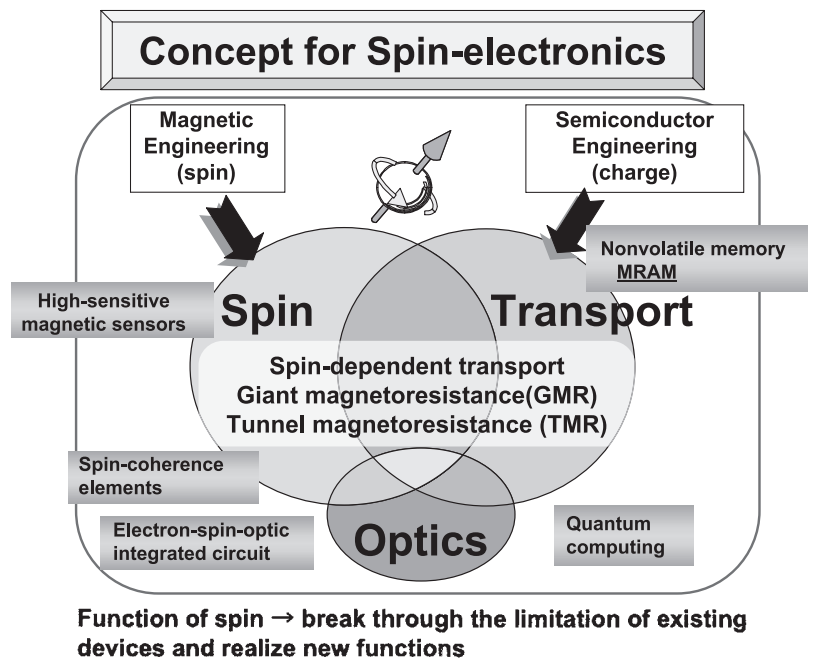

Fig.4 Concept chart of spintronics.

電子機器への応用が期待され, 関連の分野の研究を活性化さ せた，しかしながら，出力電圧を見た場合，TMR (GMR)変 化率の向上は飽和状態にあり, スピントロニクス分野の更な る発展には TMR 素子のブレイクスルーが望まれていた，

$5.1 \mathrm{MgO}$ 障壁巨大トンネル磁気抵抗効果の発見

Al-Oはアモルファスであるため, いわゆるインコヒーレン トトンネル伝導のため TMR 効果の更なる向上は期待できな かった.これに対してトンネル障壁として $\mathrm{MgO}$ を用いた $\mathrm{Fe}$ $(001) / \mathrm{MgO}(001) / \mathrm{Fe}(001)$ 構造の巨大トンネル接合 (MTJ) では 理論計算の結果 ${ }^{17,18)} 1000 \%$ 以上の高いTMR効果が期待される ことが報告された.このような中で $\mathrm{MgO}$ をトンネル障壁とす るトンネル接合の作製が試みられたが，なかなかうまくいか ず, 室温での TMR 比の值はAl-Oのそれを大きく上回ること はなかった

2004年に湯浅らは分子線エピタキシー(MBE)法を用いてエ ピタキシャル $\mathrm{Fe}(001) / \mathrm{MgO}(001) / \mathrm{Fe}(001) \mathrm{MTJ}$ 素子を作製し, 初めてアモルファス $\mathrm{Al}-\mathrm{O}$ 障壁を越える室温 TMR を実現し た ${ }^{19,20)}$. 当時のTMRの值は室温で $180 \%, 20 \mathrm{~K}$ で $245 \%$ であっ た。一方, Parkin らは ${ }^{21)}(001)$ 結晶面が優先配向した多結晶 $\mathrm{CoFe} / \mathrm{MgO} / \mathrm{CoFeMTJ}$ 素子をスパッ夕法で作製し，室温で $220 \%$ TMR 比を得た. その後多くのグループでこの MgOを トンネル障壁とする MTJ 素子が研究され, TMR 比の值は室 温で $500 \%$ ，5 K では $1000 \%$ 以上の值が報告 ${ }^{22)}$ されるととも に, HDD 用の磁気ヘッドならびに大容量MRAMの開発が進 められている.

5.2 ホイスラー電極巨大トンネル磁気抵抗効果

ホイスラー合金とは1905 年 Heuslerにより発見された合金 で, 非磁性元素のみからなる $\mathrm{Cu}_{2} \mathrm{MnAl}$ 合金が強磁性を示すこ とから興味をもたれた。この合金は $\mathrm{X}_{2} \mathrm{YZ}$ (フルホイスラー) およびXYZ (ハーフホイスラー)組成を中心とする合金で, 最 初は磁性元素を含まなかったがX=Fe, Co, Niに代表されるよ うに, 後に磁性元素を含む多くのホイスラー合金も報告され 
ている.

その後ホイスラー合金は磁性材料として話題にほとんどの ぼらなかった.3節で記述したようにTMR比は電極物質のス ピン分極率に依存し，しかも分極率 1 (完全にスピン偏極)では TMR比は無限大となる.このような物質はハーフメタルと呼 ばれ, フェルミエネルギー近傍において片方のスピンバンド にのみエネルギーギャップを有する強磁性材料である. 多く のホイスラー合金がハーフメタル的なバンド構造を有するこ とから, 室温巨大 TMR 効果の報告以降, MTJ の電極材料と してホイスラー合金が注目されることとなった.しかしなが ら, $\mathrm{MgO}$ 障壁 $\mathrm{MTJ}$ の巨大 TMR 効果の報告以前は良質な試料 が得られなかったためあまり注目されなかったが, 最近の素 子作製技術の進歩により, 界面の原子配列が制御されること に伴って，比較的大きな TMR 比のホイスラー合金電極 MTJ が報告されるようになった ${ }^{23-26)}$. Fig.5に一例として $\mathrm{Co}_{2} \mathrm{MnSi} /$ $\mathrm{Al}-\mathrm{O} / \mathrm{Co}_{2} \mathrm{MnSi} \mathrm{MTJ}$ の TMR 比の温度依存性を示す。 $M-R$ 曲 線は挿入図に示す. $\mathrm{CoFe}$ 電極を(片側および両面)用いた場合 の結果も併せて示してある. Julliereの式から見積もったスピ ン分極率は 89\%(下部)，83\%(上部)であった．界面状態を 制御することにより, 分極率がほぼ1のMTJも得られている.

実際にハーフメタルになっているかどうか, およびFig.5の 急激なTMR比の温度依存性を明らかにするため, 上述の場合 の $d I / d V-V$ 特性を测定した結果をFig.6に示す. 図からダウン スピンバンドのエネルギーギャップは $350-400 \mathrm{meV}$ と見積も られ,バンド計算の $400-600 \mathrm{meV}$ に近い值である.また, フェ ルミ面からダウンスピンバンドの伝導帯までのエネルギー (図 (b) の $\delta_{c B}$ ) は 10-20 meV と非常に小さく, これが TMR 比 の急激な温度変化の原因と考えられる。

5.3 スピントランスファートルク ${ }^{27,28)}$

3.2節で説明したようにトンネル磁気抵抗効果(GMR効果に ついても同じである) は磁化の向きにより電流をコントロー

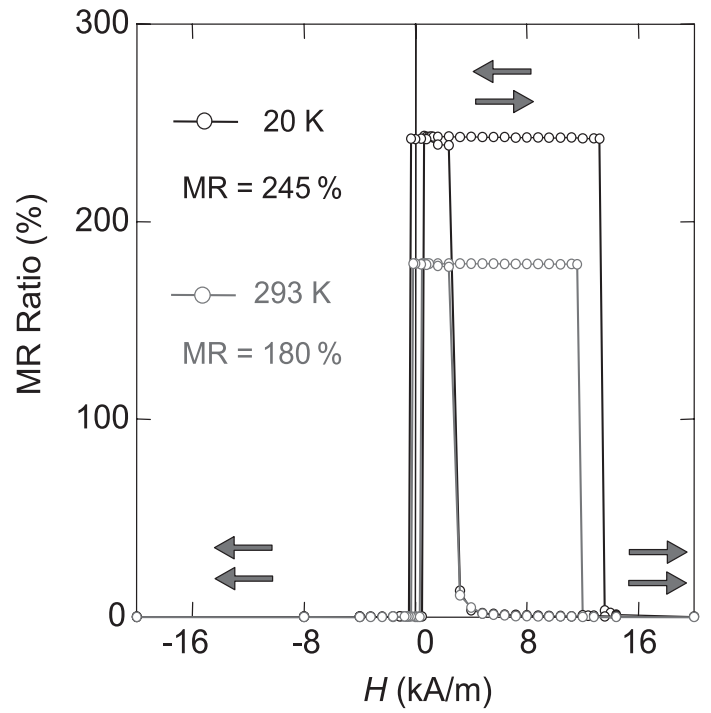

Fig.5 MR curves for epitaxial $\mathrm{Fe}(001) / \mathrm{MgO}(001) / \mathrm{Fe}(001)$ tunnel junction.
ルしている. 逆に, 電流により磁化の向きを変化させるのが スピントランスファートルクである.GMR効果の場合磁化の 相対角度により，スピン分極した電流が変化したように，こ のスピントランスファートルクを起こさせるためにスピン分 極した電流が必要となる。この物理の值感的イメージは，力 学に於けるニュートンの第 3 法則「作用と反作用の法則」に 「磁気抵抗効果とスピントランスファー効果(トルク)」が対 応していると思えばよい (Fig.8).

スピントランスファートルクをもう少し詳しく説明するた め, 強磁性 (F1)/非磁性(N)/強磁性(F2)の接合を考える(Fig.9). 接合の両端に電圧を加え電流が右から左に, 電子は左から右 に流れる.電極の電子のスピン角運動量を $S_{1}, S_{2}$ とする. 左の 電極から F1 層に入った伝導電子のスピン $S$ は $S_{1}$ によりスピ ン偏極し， $S_{1}$ の方向にそろう。このスピン偏極したスピン $S$ がF2 層に入ると $S_{2}$ との相互作用により, $S$ の角運動量が変化 し, この変化分が $S_{2}$ に移動し, 結果として $S_{2}$ はトルクを受け る. $S_{2}$ の受けるトルクの向きは $S_{2}$ と伝導電子のスピン $S$ の単 位べクトルを用いて表されるが, $S$ の向きは $S_{1}$ により決まる ため，結果的に $S_{1}$ と $S_{2}$ により表される。

興味があることは電流の向きにより，このトルクは $S_{2}$ の運 動を減衰させる方向と, スピンを反転させる方向に㗢く. Slonczewskiの計算によると，スピンの反転の条件は

$$
\alpha M_{S} V H_{e f f}<g \frac{\hbar}{2} \frac{|I|}{e}
$$

で与えられる.ここでの $\alpha, M_{s}, V, H_{e f f}$ はF2のそれぞれ才差運 動の制動の程度を表すダンピング定数, 飽和磁化, 体積, 有 効磁界を表す. $g$ はスピントランスファー効率係数でスピン 分極率の関数である. $\hbar / 2, I, e$ はそれぞれスピン1ケの角運動 量, 電流および素電荷である。

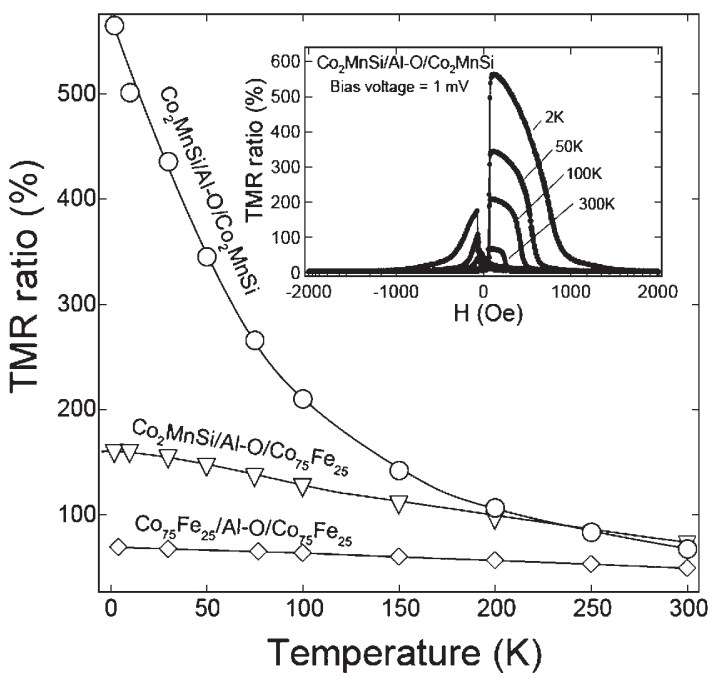

Fig.6 Temperature dependence of TMR ratio for the $\mathrm{Co}_{2} \mathrm{MnSi} / \mathrm{Al}-$ $\mathrm{O} / \mathrm{CO}_{2} \mathrm{MnSi} \mathrm{MTJ}$. Data for the $\mathrm{Co}_{2} \mathrm{MnSi} / \mathrm{Al}-\mathrm{O} / \mathrm{CO}_{75} \mathrm{Fe}_{25}$ and $\mathrm{CO}_{75} \mathrm{Fe}_{25} / \mathrm{Al}-\mathrm{O} / \mathrm{Co}_{75} \mathrm{Fe}_{25}$ MTJ's are shown for comparison. TMR curves at the corresponding temperature are shown in the inset. 


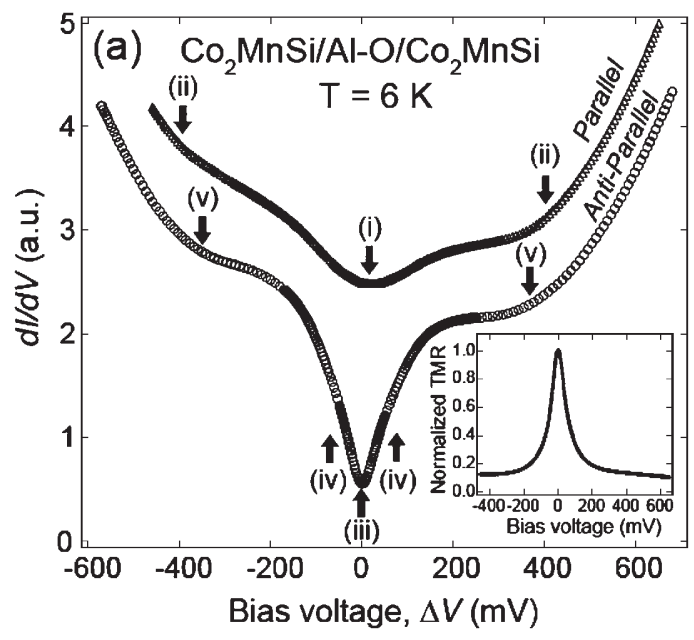

(b) $\mathrm{Co}_{2} \mathrm{MnSi}$

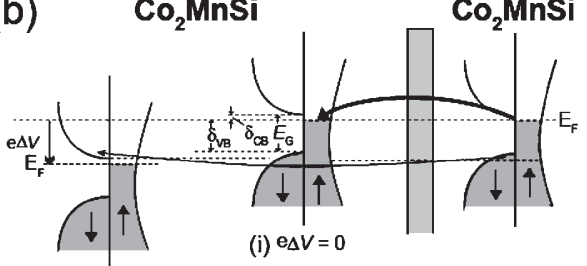

(ii) $e_{\Delta} V>E_{G}$



(v) $e \Delta V>\delta_{v B}$ (iii) $e_{\Delta V}=0$

Anti-parallel

Fig.7 (a) Dependence of tunnel conductance on bias voltage (dII $d V-V$ ) for a MTJ. (b) Schematic of normalized TMR ratio on bias voltage for a MTJ with $\mathrm{Co}_{2} \mathrm{MnSi} / \mathrm{Al}-\mathrm{O} / \mathrm{Co}_{2} \mathrm{MnSi}$ structure. Inset shows the dependence of normalized TMR ratio on bias voltage. (b) Schematic of electron tunneling process at finite bias voltage for the junction for both parallel and anti-parallel configurations.



Fig.8 Relationship between TMR (GMR) effects and spin-transfer effect.

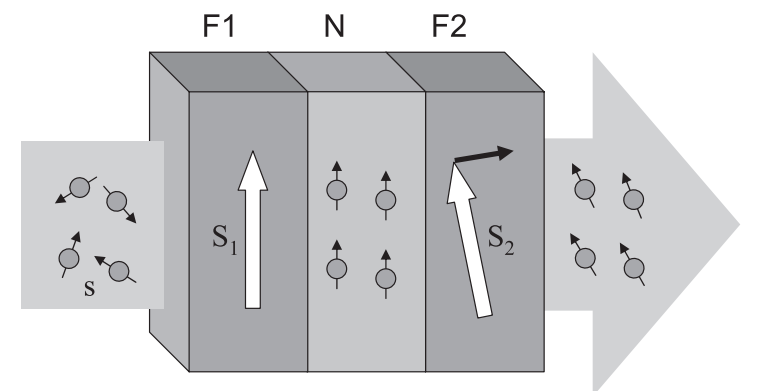

Fig.9 Schematic explanation of spin-transfer effect for Ferro(F1)/ Non-magnetic/Ferro(F2) junction. Large arrow crossed from left to right shows spin current. Small arrows with sphere show the spins of conduction electrons. White arrows $S_{1}$ and $S_{2}$ are spins for F1 and F2, respectively.

この物理を用いて, 磁気メモリの磁化をコントロールする 研究が精力的にすすめられている. 高密度 (> Gbits)のメモリ に於いてはセルサイズが $100 \mathrm{~nm}$ 以下と小さくなるため, 従来 の磁界反転方式だと大きな電流を必要とするが, このスピン トランスファートルクを用いた磁化反転技術だと, 逆にセル サイズの減少に伴って, 小さな電流で反転が可能となるからで ある. 当初はGMR接合について実験が報告されていたが29-31), 最近ではTMR接合についての報告が主流となっている. スピ ントランスファー磁化反転を用いた磁気メモりは特にスピン RAM と呼ばれ, 要求されるスピン注入電流は $5 \times 10^{5} \mathrm{~A} / \mathrm{cm}^{2}$ で, かつE/ $k_{B} T>60$ の熱的安定性が保証されることである. Table 1

Table 1 Summarized results for critical current density $\left(J_{c 0}\right)$ and thermal stability $\left(\Delta=E / k_{B} T\right)$.

\begin{tabular}{cccccccc}
\hline Group & Barrier & $\begin{array}{c}J_{\mathrm{CO}} \\
\left(\mathrm{MA} / \mathrm{cm}^{2}\right)\end{array}$ & $\begin{array}{c}\mathrm{TMR} \\
(\%)\end{array}$ & $\begin{array}{c}R A \\
\left(\Omega \mu \mathrm{m}^{2}\right)\end{array}$ & $\Delta$ & $\begin{array}{c}M_{\mathrm{S}} \text { (CoFeB) } \\
(\mathrm{emu} / \mathrm{cc})\end{array}$ & Ref. \\
\hline Sony & $\mathrm{Al}-\mathrm{O}$ & 6.4 & 30 & 14 & 28 & $(\mathrm{NiFe})$ & 32 \\
\hdashline AIST & $\mathrm{MgO}$ & 12 & 100 & 3 & - & 1200 & 33 \\
\hdashline Grandis & $\mathrm{Al}-\mathrm{O}$ & 2.2 & 25 & 10 & 42 & 1000 & 34 \\
\hdashline Grandis & $\mathrm{MgO}$ & 2 & 150 & 50 & -30 & 800 & 35 \\
\hdashline AIST & $\mathrm{MgO}$ & 10 & 140 & 4 & 40 & 1100 & 36 \\
\hdashline Sony & $\mathrm{MgO}$ & 2 & 160 & 20 & 30 & - & 37 \\
\hdashline RIEC & $\mathrm{MgO}$ & 8.6 & 90 & 5 & 67 & $(\mathrm{SynF})$ & 38 \\
\hdashline Grandis & dual-MgO & 1.0 & 70 & 100 & $(-50)$ & 800 & 39 \\
\hdashline Tohoku & $\mathrm{MgO}$ & 6.7 & 110 & 7 & 33 & 1300 & 40 \\
\hline
\end{tabular}

$\Delta=E / k_{\mathrm{B}} T$

SynF : Synthetic ferrimagnetic structure 
には最近の臨界電流密度 $J_{c 0}$ (熱による効果を除いた値) とセ ルの熱安定性の実験結果を示した ${ }^{32-40)}$. 両者を十分に満足し た接合は今のところ報告されておらず, 今後の更なる進展に 期待する.

スピントランスファートルク以外にも興味ある現象が報告 されつつあるが，紙面の都合により割愛する.

\section{謝辞}

最後に, 我々の研究は多くの助成を受けて行われてきたが, 最近のホイスラー電極 TMR およびスピン注入磁化反転の研 究は主に文部科学省のITプログラムRR2002および科学研究 費補助金, 総務省の戦略的情報通信研究開発制度の助成によ り行われた。

\section{文献}

1) G.Binasch, P.Grüunberg, F.Saurenbach and W.Zinn: "Enhanced magnetoresistance in layered magnetic structures with antiferromagnetic interlayer exchange", Phys. Rev. Lett., 39(1989)4828-4830.

2) M.N.Baibich, J.M.Broto, A.Fert, F.Nguyen Van Dau, F.Petroff, P.Eitenne, G.Greuzet, A.Friederich and J.Chazelas: "Giant Magneoresistance of (001)Fe/(001)Cr Magnetic Superlattices", Phys. Rev. Lett., 61(1988)2472-2475.

3) T.Miyazaki and N.Tezuka: "Giant magnetic tunneling effect in $\mathrm{Fe} / \mathrm{Al}_{2} \mathrm{O}_{3} / \mathrm{Fe}$ junction", J. Magn. Magn. Mater., 139(1995) L231-L234.

4) J.S.Moodera, L.R.Kider, T.M.Wong and R.Meservey: "Large Magnetoresistance at Room Temperature in Ferromagnetic Thin Film Tunnel Junctions", Phys. Rev. Lett., 74(1995)32733276.

5) T.Miyazaki: Spintronics, Nikkan Kogyo Shimbunsha, (2007) P.69.

6) T.R.Mcguire and R.I.Potter: "Anisotropic Magnetoresistance in Ferromagnetic 3d Alloys", IEEE Trans. Mag., 4(1975) 1018 1038.

7) I.A.Campbell, A.Fert and O.Jaoul: "The spontaneous resistivity anisotropy in Ni-based alloys", J. Phys. C, 1(1970)S95-S101.

8) S.Von Molnar and S.Methfessel: "Giant Negative Magnetoresistance in Ferromagnetic $\mathrm{Eu}_{1-x} \mathrm{Gd}_{\mathrm{x}} \mathrm{Se}$ ", J. Appl. Phys., 38(1967)959-964.

9) S.D.Bader: "Thin film magnetism", Proceedings of the IEEE, 78(1990)909-922.

10) T.Shinjo: "Interface magnetism", Surface science reports, 12 (1991) 51-98.

11) P.Grünberg: "Layerd Magnetic Structures: History, Highlights, Applications", Physics Today, (2001)31-37.

12) T.Miyazaki: "Spin tunneling Magnetoresistive Effect", J. Magn. Soc. Jpn., 20(1996)896-904.

13) M.Sato and K.Kobayashi: "Spin-Valve-Like Properties of
Ferromagnetic Tunnel junctions", Jpn. J. Appl. Phys., 36(1997) L200-L201.

14) W.J.Gallagher, S.S.P.Parkin, Y.Lu, X.P.Bian, A.Marley, K.P.Roche, R.A.Altman, S.A.Rishton, C.Jahnes, T.M.Shaw and G.Xiao: "Microstructured magnetic tunnel junctions", J. Appl. Phys., 81(1997)3741-3746.

15) T.Miyazaki: "Review of the Development of Spin Tunnel Junctions and Future Problems", J. Magn. Soc. Jpn., 25(2001) 471-477.

16) WTEC Panel Report on Spin Electronics, (2003).

17) J.Mathon and A.Umerski: "Theory of tunneling magnetoresistance of an epitaxial $\mathrm{Fe} / \mathrm{MgO} / \mathrm{Fe}(001)$ junction", Phys. Rev. B, 63(2001)220403-1-4.

18) W.H.Butler, H.-G.Zhang, T.C.Schulthess and J.M.Maclaren: "Spin-dependent tunneling conductance of $\mathrm{Fe} / \mathrm{MgO} / \mathrm{Fe}$ sandwiches", Phys. Rev. B, 63(2001)054416-1-12.

19) S.Yuasa, A.Fukushima, T.Nagahama, K.Ando and Y.Suzuki: "High Tunnel Magnetoresistance at Room Temperature in Fully Epitaxial $\mathrm{Fe} / \mathrm{MgO} / \mathrm{Fe}$ Tunnel Junctions due to Coherent SpinPolarized Tunneling", Jpn. J. Appl. Phys., 43(2004)L588-L590.

20) S.Yuasa, T.Nagahama, A.Fukushima, Y.Suzuki and K.Ando: "Giant room-temperature magnetoresistance in single-crystal $\mathrm{Fe} / \mathrm{MgO} / \mathrm{Fe}$ magnetic tunnel junctions", Nature Materials, 3 (2004) 868-871.

21) S.S.P.Parkin, C.Kaiser, A.Panchula, P.M.Rice, B.Hughes, M.Samant and S.-H.Yang: "Giant tunneling magnetoresistance at room temperature with $\mathrm{MgO}(100)$ tunnel barriers", Nature Materials, 3(2004)862-867.

22) S.Ikeda, J.Hayakawa, Y.M.Lee, R.Sasaki, T.Meguro, F.Matsukura and H.Ohno: "Dependence of Tunnel Magneoresistance in MgO Based Magnetic Tunnel Junctions on Ar Pressure during MgO Sputtering", Jpn. J. Appl. Phys., 44(2005)L1442-L1445.

23) Y.Sakuraba, M.Hattori, M.Oogane, Y.Ando, A.Sakuma and T.Miyazaki: "Giant tunneling magnetoresistance in $\mathrm{Co}_{2} \mathrm{MnSi} /$ $\mathrm{Al}-\mathrm{O} / \mathrm{Co}_{2} \mathrm{MnSi}$ magnetic tunnel junctions", Appl. Phys. Lett., 88(2006) 19208-1-3.

24) Y.Sakuraba, T.Miyakoshi, M.Oogane, Y.Ando, A.Sakuma and T.Miyazaki: "Direct observation of half-metallic energy gap in $\mathrm{CO}_{2} \mathrm{MnSi}$ by tunneling conductance spectroscopy", Appl. Phys. Lett., 89(2006)052508-1-3.

25) N.Tezuka, N.Ikeda, S.Sugimoto and K.Inomata: "175\% tunnel magnetoresistance at room temperature and high thermal stability using $\mathrm{Co}_{2} \mathrm{FeAl}_{0.5} \mathrm{Si}_{0.5}$ full-Heusler alloy electrodes", Appl. Phys. Lett., 89(2006)252508-1-3.

26) T.Ishikawa, T.Marukame, H.Kijima, K.I.Matsuda, T.Uemura, M.Arita and M.Yamamoto: "Spin-dependent tunneling characteristics of fully epitaxial magnetic tunneling junctions with a full-Heusler alloy $\mathrm{CO}_{2} \mathrm{MnSi}$ thin film and a $\mathrm{MgO}$ tunnel 
barrier", Appl. Phys.Lett., 89(2006)192505-1-3.

27) J.C.Slonczewski: "Current-driven excitation of magnetic multilayers", J. Magn. Magn. Mater., 159(1996)L1-L7.

28) L.Berger: "Emission of spin waves by a magnetic multilayer traversed by a current", Phys. Rev. B, 54(1996)9353-9358.

29) M.Tsoi, A.G.M.Jansen, J.Bass, W.-C.Chiang, M.Seck, V.Tsoi and P.Wyder: "Excitation of a Magnetic Multilayer by an Electric Current", Phys. Rev. Let., 80(1998)4281-4284.

30) E.B.Mayers, D.C.Ralph, J.A.Katine, R.N.Louie and R.A.Buhrman: "Current-Induced Switching of Domains in Magnetic Multilayer Devices", Science, 285(1999)867-870.

31) J.A.Katine, F.J.Albert, R.A.Buhrman, E.B.Mayers and D.C.Ralph: "Current-Driven Magnetization Reversal and SpinWave Excitations in $\mathrm{Co} / \mathrm{Cu} / \mathrm{Co}$ Pillars", Phys. Rev. Lett., 84 (2000)3149-3152.

32) Y.Higo, K.Yamane, K.Ohba, H.Narisawa, K.Bessho, M.Hosomi and H.Kano: "Thermal activation effect on spin transfer switching in magnetic tunnel junctions", Appl. Phys. Lett., 87(2005)082502-1-3.

33) H.Kubota, A.Fukushima, Y.Ootani, S.Yuasa, K.Ando, H.Maehara, K.Tsunekawa, D.D.Djayaprawira, N.Watanabe and Y.Suzuki: "Evaluation of Spin-Transfer Switching in CoFeB/ $\mathrm{MgO/CoFeB} \mathrm{Magnetic} \mathrm{Tunnel} \mathrm{Junctions",} \mathrm{Jpn.} \mathrm{J.} \mathrm{Appl.} \mathrm{Phys.,}$ 40(2005)L1237-L1240.

34) Y.Huai, M.Pakala, Z.Diao and Y.Ding: "Spin-transfer switching current distribution and reduction in magnetic tunneling junction-based structures", IEEE Trans. Magn., 40 (2005)2621-2626.

35) Z.Diao, D.Apalkov, M.Pakala and Y.Ding: "Spin transfer switching and spin polarization in magnetic tunnel junctions with $\mathrm{MgO}$ and AlOx barriers", Appl. Phys. Lett., 87(2005) 232502-1-3.

36) H.Kubota, A.Fukushima, Y.Ootani, S.Yuasa, K.Ando, H.Maehara, K.Tsunekawa, D.D.Djayaprawia, N.Watanabe and Y.Suzuki: "Dependence of spin-transfer switching current on free layer thickness in $\mathrm{Co}-\mathrm{Fe}-\mathrm{B} / \mathrm{MgO} / \mathrm{Co}-\mathrm{Fe}-\mathrm{B}$ magnetic tunnel junctions", Appl. Phys. Lett., 89(2006) 132505-1-3.

37) T.Yamamoto, M.Hosomi, H.Yamagishi, K.Bessho, Y.Higo, K.Yamane, H.Yamada, M.Shiji, H.Yamagishi, C.Fukumoto, H.Nagao and H.Kano: "Spin transfer magnetization switching memory", J. Magn. Soc. J., 148(2006)31-36.

38) J.Hayakawa, S.Ikeda, Y.M.Lee, R.Sasaki, T.Meguro, F.Matsukura, H.Takahashi and H.Ohno: "Current-Induced Magnetization Switching in MgO Barrier Based Magnetic Tunnel junctions with $\mathrm{CoFeB} / \mathrm{Ru} / \mathrm{CoFeB}$ Synthetic Ferrimagnetic Free Layer", Jpn. J. Appl. Phys., 45(2006) L1057-1060.

39) Z.Diao, A.Panchula, Y.Ding, M.Pakala, S.Wang, Z.Li, D.Apalkov, H.Nagai, A.Drinskii, S. Lien, C.Wanf, E.Chen and Y.Huai: "Spin transfer in dual MgO magnetic tunnel junctions", Appl. Phys. Lett., 90(2007)132508-1-3.

40) D.Watanabe, et al.: unpublished. 